Description and proposed life cycle of Maritrema novaezealandensis $\mathbf{n}$. sp. (Microphallidae) parasitic in red-billed gulls, Larus novaehollandiae scopulinus, from Otago Harbor, South Island, New Zealand

Martorelli, Sergio R; Fredensborg, Brian Lund; Mouritsen, Kim Nørgaard; Poulin, Robert

Published in:

Journal of Parasitology

DOI:

10.1645/GE-3254

Publication date:

2004

Citation for published version (APA):

Martorelli, S. R., Fredensborg, B. L., Mouritsen, K. N., \& Poulin, R. (2004). Description and proposed life cycle of Maritrema novaezealandensis n. sp. (Microphallidae) parasitic in red-billed gulls, Larus novaehollandiae scopulinus, from Otago Harbor, South Island, New Zealand. Journal of Parasitology, 90(2), 272-7.

https://doi.org/10.1645/GE-3254 


\title{
DESCRIPTION AND PROPOSED LIFE CYCLE OF MARITREMA NOVAEZEALANDENSIS N. SP. (MICROPHALLIDAE) PARASITIC IN RED-BILLED GULLS, LARUS NOVAEHOLLANDIAE SCOPULINUS, FROM OTAGO HARBOR, SOUTH ISLAND, NEW ZEALAND
}

\author{
Sergio R. Martorelli, Brian L. Fredensborg*, Kim N. Mouritsen*, and Robert Poulin* \\ Centro de Estudios Parasitologicos y Vectores (CEPAVE), Calle 2, no. 584, 1900 La Plata, Argentina. e-mail: sergio@cepave.com.ar
}

\begin{abstract}
Maritrema novaezealandensis n. sp. is described from Otago Harbor, South Island, New Zealand, on the basis of adult specimens collected from the Red-billed gull, Larus novaehollandiae scopulinus, and excysted metacercariae obtained from crabs. It belongs to the "eroliae group" and differs from other related species mainly in the shape, size, and patterns of distributions of the spines on the cirrus, the shape of the metraterm, the presence of an unlobed ovary, and the complete ring of the vitelline follicles. Based on morphometric features of metacercariae and adult specimens, the trophic relationships among invertebrate and vertebrate hosts, experimental infections, and previous reports of species of Maritrema with similar transmission patterns, the life cycle of M. novaezealandensis n. sp. is described. A 3-host life cycle is proposed for this parasite. The first intermediate host is the mud snail, Zeacumantus subcarinatus, in which the cercarial stage is produced in sporocysts located within the gonad of the snail. At least 3 crab species (Hemigrapsus crenulatus, Macrophtalmus hirtipes, and Halicarcinus whitei) and several species of amphipods act as second intermediate hosts, with metacercariae encysted in the body cavity of the crustacean host. Finally, the definitive host, the gull, L. n. scopulinus, harbors the adult worms in its intestine.
\end{abstract}

A total of 9 species of Maritrema Nicoll, 1907 (Digenea: Microphallidae) have been reported from marine birds in Australia and Tasmania: M. ornithorhynchi by Hickman (1955), M. eroliae and M. oocysta by Deblock and Pearson (1968), M. calvertensis and M. eroliae by Smith (1974, 1983), M. brevisacciferum by Shimazu and Pearson (1991), and M. spinulosusm, M. eroliae, M. rubeum, and Maritrema sp. by Deblock and Canaris (1996). However, no species of this genus has been reported from New Zealand.

The aim of the present study was to describe a new species of Maritrema from the Red-billed gull, Larus novaehollandiae scopulinus (Forster, 1844), in New Zealand, and all its life cycle stages found in the first intermediate host, the mud snail, Zeacumantus subcarinatus (Sowerby, 1855) (Mollusca: Batillariidae), and in the second intermediate hosts, the crabs, Hemigrapsus crenulatus (Milne Edwards, 1837) (Crustacea: Grapsidae), Macrophtalmus hirtipes (Heller, 1862) (Crustacea: Ocypodidae), and Halicarcinus whitei (Miers, 1876) (Crustacea: Hymenosomatidae).

\section{MATERIALS AND METHODS}

Thirty infected mud snails, Z. subcarinatus, collected by hand in Oyster Bay, Otago Harbor, South Island, New Zealand $\left(45^{\circ} 47^{\prime} \mathrm{S}\right.$, $170^{\circ} 42^{\prime} \mathrm{E}$ ), were incubated individually in $5-\mathrm{ml}$ petri dishes at $25 \mathrm{C}$ and under constant illumination to facilitate cercarial emission. Cercariae were studied alive and then fixed in 5\% formalin for measurements. Ten infected snails were crushed for sporocyst examination, and the larval stage was fixed in 5\% formalin. Live cercariae from naturally infected snails were used to infect potential intermediate host, crabs and amphipods. Five uninfected juvenile $H$. crenulatus crabs (carapace width 4-6 mm) were held in a small aquarium with 5 infected snails for $6 \mathrm{wk}$. At the end of this period, metacercariae in different stages of development and encystment were dissected from these crabs and processed as those obtained from naturally infected hosts (see below). In addition, 30 uninfected amphipods, Paracalliope sp., were individually exposed to 5-10 cercariae in small vials and dissected 5 wk later; the metacercariae recovered were treated as described below.

Encysted metacercariae collected from the body cavities of naturally

Received 21 April 2003; revised 15 September 2003; accepted 15 September 2003.

* Department of Zoology, University of Otago, P.O. Box 56, Dunedin, New Zealand. infected $H$. crenulatus $(\mathrm{n}=180), M$. hirtipes $(\mathrm{n}=50)$, and $H$. whitei $(\mathrm{n}=5)$, obtained from Company Bay and Waipuna Bay (Otago Harbor) and Papanui Inlet (Otago Peninsula), were placed in small petri dishes containing saline solution at $40-42 \mathrm{C}$ to facilitate excystment. Some excysted metacercariae kept under these conditions for $24-48 \mathrm{hr}$ to achieve precocious egg production were killed in hot saline solution, fixed in AFA, and maintained in 5\% formalin until stained. Finally, a total of 16 Red-billed gulls, L. n. scopulinus, obtained from Otago Harbor between February and July 2002 were frozen and later dissected for parasites; the adult worms recovered were fixed in AFA. Some specimens were in poor condition; however, the protected status of the endemic Red-billed gull precludes the acquisition of further specimens.

Metacercariae and adults were stained in Semichon's acetocarmine or Van Cleave's hematoxylin, with several drops of Ehrlich's hematoxylin added, dehydrated in an ethanol series, cleared in clove oil, and mounted in Canada balsam. Formalin-fixed adults that were in poor condition were pipetted into $70 \%$ ethyl alcohol, hydrated by slowly adding drops of distilled water, and mounted in a hydrated media, polyvinyl alcohol-lactofenol, without coloration to avoid body contraction in the dehydration process. These specimens were used only for observations. All drawings were made with the aid of a camera lucida. The measurements of the sporocyst, cercariae, and metacercariae are based on stained and mounted specimens and are given in micrometers as a range, followed by the mean and standard deviation in parentheses. The measurements of the adult specimens are those of the holotype, followed by the range of values from the other specimens in parentheses.

The holotype, paratypes, and voucher specimens of excysted metacercariae were deposited in the Museo de La Plata, La Plata, Argentina, Helminthological Collection (MPHC).

\section{DESCRIPTION}

Maritrema novaezealandensis $\mathrm{n} . \mathbf{s p}$.

(Figs. 1-4)

Adult: Descriptions based on 6 mounted specimens. Body oval to elongate, spinous, 350 (350-470) long by $130(130-175)$ wide at acetabular level. Oral sucker (OS) subterminal, 28 (28-32) long by 23 (2332) wide; ventral sucker (VS) 30 (28-35) long by 29 (28-36) wide. Sucker length ratio (VS/OS) is 1.07. Prepharynx 60 (20-60) long; pharynx 22 (22-28) long by 18 (18-20) wide. Esophagus 60 (40-60) long, intestinal ceca $110(110-140)$ long, extending to the middle of the acetabulum. Testes oval, symmetrical, postovarian; left testis $20(20-40)$ long by 39 (39-50) wide; right testis 25 (25-45) long by 40 (30-40) wide. Cirrus-sac thin walled, curved, 175 (150-180) long, between intestinal ceca and VS, with the base very close to the right testis. Ratio between cirrus-sac length and body length $(\mathrm{CSL} / \mathrm{BL})=0.50(0.45-$ $0.50)$. Cirrus-sac containing seminal vesicle, numerous prostatic cells, ejaculatory duct, pars prostatica, and spinous cirrus. Invaginated cirrus 

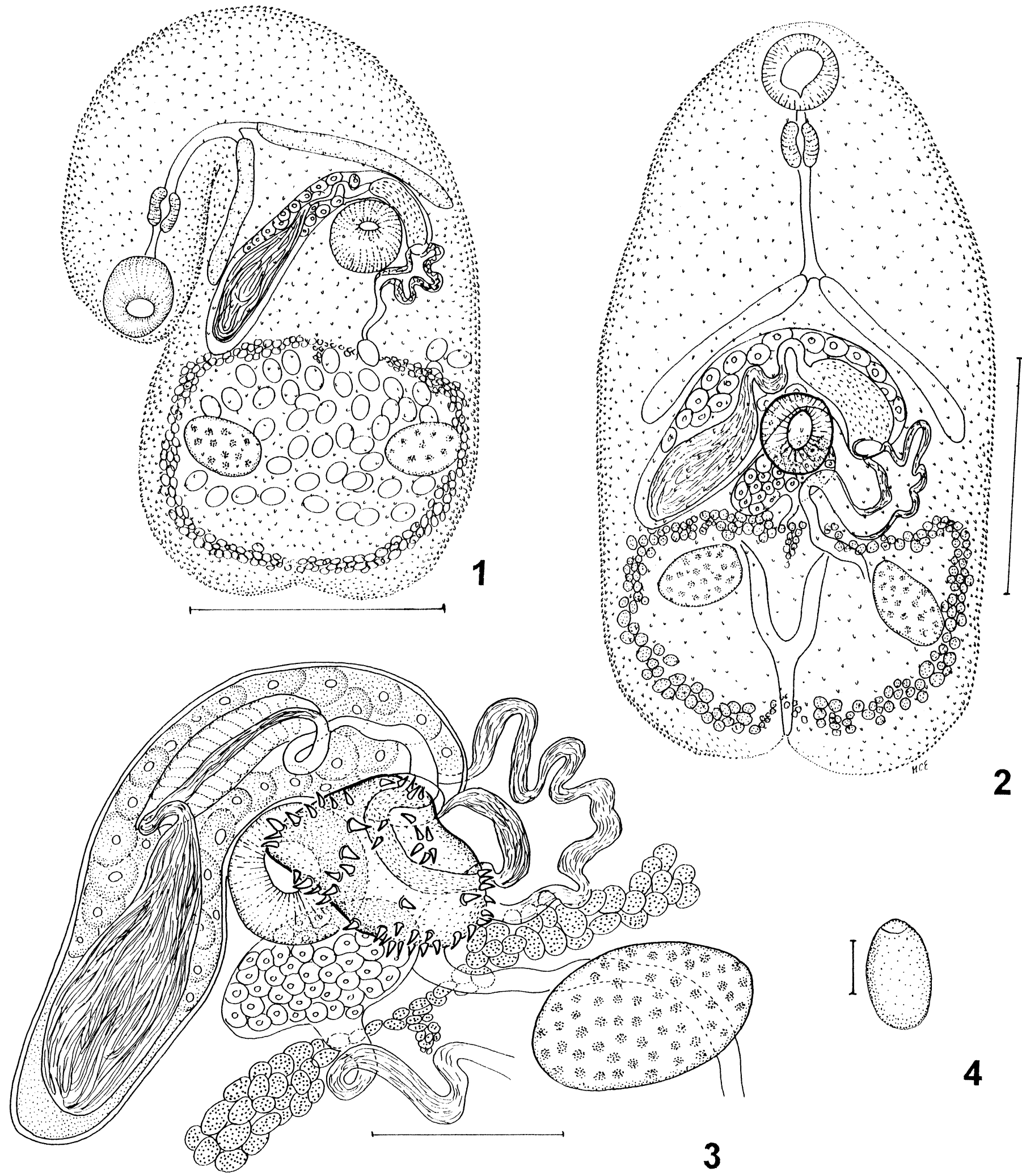

FIGURE 1. Maritrema novaezealandensis n. sp. Adult ventral view. Bar $=100 \mu \mathrm{m}$.

FIGURE 2. Maritrema novaezealandensis n. sp. Ventral view of 24-hr-old metacercaria. Bar $=100 \mu \mathrm{m}$.

FIGURE 3. Maritrema novaezealandensis n. sp. Metacercaria, detail of the terminal genitalia with evaginated cirrus. Bar $=50 \mu \mathrm{m}$.

FiguRE 4. Maritrema novaezealandensis n. sp. Detail of operculate egg. Bar $=8 \mu \mathrm{m}$. 
50 (50-80) long by 20 (20-30) wide. Cirrus was not evaginated in adult specimens and is described based on 24- to 48-hr-old cultured metacercariae. Cirrus 52-68 (60 \pm 8$)$ long by 30-42 (36 \pm 6$)$ wide at base. Small spines covering entire surface of cirrus; several large spines disposed around border and on medial zone. All these spines were of the same size, with only 2 midbasal and distal one larger. Ductus ejaculatorius with rows of small spines. Ovary middle, postacetabular, partially covered by posterior border of VS. Metraterm thick walled and diverticulated. Seminal receptacle, ootype, and Laurer's canal not evident Genital pore left of acetabulum. Eggs numerous, operculated, 17 (1619) long by 11 (10-11) wide (Fig. 4). Vitellarium in a complete ring near the margin of the body. Excretory vesicle not visible.

\section{Taxonomic summary}

Type hosts: Larus novaehollandiae scopulinus (Forster, 1844) (Aves: Laridae).

Type locality: Otago Harbor, South Island, New Zealand (45 47' S, $\left.170^{\circ} 42^{\prime} \mathrm{E}\right)$.

Specimens deposited: MPHC, holotype (no. 5279) and 7 paratypes (no. 5280) (adults and fully developed metacercariae).

Site of infection: Intestine.

Prevalence: $56 \%$ (9 infected birds of 16 examined).

Etymology: The specific name is derived from the name of the country (New Zealand) where the hosts were collected and -"ensis" (L. belonging to).

\section{Remarks}

According to the characteristics of microphallid digeneans given by Deblock (1971), the new species can be included in Maritrema Nicoll, 1907. The morphological features of this new species fit with the "eroliae group" revised by Deblock and Canaris (1992) and, within it, are more closely related to the group A that includes 6 species, less than $400 \mu \mathrm{m}$ in total length. This group includes: $M$. patulus Coil, 1955; $M$. magdalenense Werding, 1973; M. borneoense Fischthal \& Kuntz, 1973; M. minuta Ke, 1976; M. macropharynga Ke, 1976; and M. jilinensis Zhong, Ke-Feng \& Min-Shen, 1988. All 6 species differ from M. novaezealandensis $\mathrm{n}$. $\mathrm{sp}$. in having the vitellarium forming, totally or in part, an incomplete ring. In addition, M. patulus differs from the new species in having a larger U-shaped cirrus of $120-150$ by $25 \mu \mathrm{m}$ in diameter, covered only with fine spines. Maritrema magdalenense differs from $M$. novaezealandensis by its smaller body size of $320 \mu \mathrm{m}$ and by the morphology of its cirrus sac and the cirrus that seems to be without spines (Deblock and Canaris, 1992). Maritrema borneoense can be distinguished from the new species by its smaller size (265-300 long), the shape of the ovary that is trilobed, larger eggs (25-28 long), and by the cirrus shape and the size and distribution of the spines on it (3-7 long, and on the distal half). Maritrema minuta differs from $M$. novaezealandensis $\mathrm{n}$. sp. by its smaller size (254 long), its triangular body, shorter prepharynx and esophagus, and by the smaller cirrus $(25$ by 73 ) and the spines on it. Maritrema macropharynga differs from our species mainly in being shorter (294 long), having a larger pharynx (44 long), and having an ovary with an irregular margin. Finally, M. jilinensis can be distinguished from the new species by its body shape (pear shaped), lobed testis, lobed ovary (with 6-13 lobes), and by having minute spines on the cirrus.

With respect to the species reported after the revision of Deblock and Canaris (1992), the new species can be compared, on the basis of the cirrus morphology, with $M$. spinosulum Deblock \& Canaris 1996, M. rubeum Deblock \& Canaris 1996, M. eroliae Yamaguti 1939, and Mar itrema sp. Deblock \& Canaris 1996, all reported from Tasmania and Australia by Deblock and Canaris (1996). Maritrema spinosulum can be distinguished from the new species by its smaller size (300-350), trilobed ovary, smaller eggs, the shape and size of the cirrus, the smaller size of spines that cover the evaginated cirrus, the smaller extension of the intestinal ceca, and the horseshoe shape of the vitellaria. Maritrema rubeum differs from $M$. novaezealandensis $\mathrm{n}$. $\mathrm{sp}$. by the different ratio of sucker sizes (VS/OS $=1.19$ ), horseshoe shape of the vitellaria, and the presence of an unfolded metraterm. Maritrema sp. differs from our new species mainly in its smaller size (192), smaller esophagus and extension of the intestinal ceca, and smaller cirrus pouch (93). This last species, according to Deblock and Canaris (1996), appears to be $M$. macropharynga Ke, 1976. Maritrema eroliae can be distinguished from M. novaezealandensis $\mathrm{n}$. sp. by its trilobed ovary, the different shape of the metraterm, and the shape, size, and patterns of distributions of the spines on the cirrus.

In relation to the remaining species reported from the geographically related areas of Australia and Tasmania, the new species can be clearly distinguished from $M$. oocysta, M. ornithorhynchi, M. calvertensis, and $M$. brevisacciferum by the presence of a spinous cirrus belonging to the eroliae group, instead of an aspinous cirrus. Finally, M. eroliae sensu Smith 1981 reported from Tasmania differs from $M$. novaezealandensis $\mathrm{n}$. sp. in being larger (620-794) and also in cirrus sac length (323-380), cirrus length (150 long in the original figure), the size and pattern of distribution of spines on the cirrus, larger extension of the intestinal ceca, the more posterior position of the testes, and by the larger metacercarial cyst (420-485).

\section{Life cycle stages}

Sporocysts (Fig. 5): Description based on 10 formalin-fixed specimens. Sporocysts were found in the gonads of the mud snail, Z. subcarinatus, as short sacs more or less elongate, 170-250 (209 \pm 31$)$ long by $80-130(110 \pm 14)$ wide. Smaller individuals were more ovoid, and the body wall was thinner. The number of cercariae contained in each sporocyst was 5-10 in the larger specimens. A birth pore was not discernible. Prevalence in snails varies among sites from 0 to $80 \%$.

Cercariae (Fig. 7): Description based on live and fixed specimens. Measurements taken on 10 heat-killed and formalin-fixed cercariae Small monostome xiphidiocercaria. Body oval to elongate, 75-94 (86 $\pm 8.1)$ long by 29-36 (32 \pm 3.2) wide, covered with minute spines Tail 70-96 (85 \pm 7.6$)$ long by $8-15(10 \pm 91.9)$ wide at base. OS 18 20 (19.2 \pm 0.9) in diameter. Stylet 12-15 (14 \pm 1.1$)$ long and 1.6-2.5 ( $2 \pm 0.44)$ wide, subcylindrical, with a small ventrally directed sharp point (in side view) and lateral protuberances (in dorsal view). Digestive system not observed. VS vestigial. Four pairs of cephalic glands near the equatorial region of body. Ducts open in pairs into small pores anterior to OS and lateral to stylet. The 2 anterior pairs of cephalic glands more evident; posterior pairs filled with fine granular inclusions. Excretory bladder $\mathrm{Y}$ shaped, opening into the posterior body extremity. Flame cell formula $2[(2+2)+(2+2)]=16$.

Metacercariae (Figs. 2, 6, 8): Description based on 10 specimens mounted and measured. Metacercarial cyst of 250-350 (308 \pm 46$)$ by 215-314 (257 \pm 44$)$, with a bilayered wall. The outer layer is 20-40 $(27 \pm 7.4)$ thick, and the inner layer is $10-13(11 \pm 1.2)$ thick. In some specimens, the external layer was enlarged (Fig. 8). The origins of these walls were not determined, but according to Galaktionov et al. (1997), they could be derived from parasite tegument. In some microphallid metacercariae, a more external layer is present, formed in an encapsulation process by host haematocytes (Overstreet, 1983; Martorelli and Schuldt, 1990). Excysted metacercariae closely resemble adults except for absence of eggs. Body oval to elongate, 310-410 (367 \pm 32$)$ long by $143-210(184 \pm 21)$ wide at acetabular level. Body surface fully covered with spines. OS subterminal, 30-38 (34 \pm 2.5$)$ long by 32-38 $(34 \pm 1.9)$ wide; VS $34-40(38 \pm 2.3)$ long by $32-40(36 \pm 2.6)$ wide. Sucker ratio (VS/OS) is 1.1. Prepharynx 10-50 (35 \pm 14$)$ long; pharynx 20-28 (22 \pm 2.9$)$ long by 14-20 (17 \pm 2.6$)$ wide. Esophagus 35-60 $(49 \pm 8.8)$ long; intestinal ceca 100-136 (117 \pm 11.7$)$, reaching the middle of the acetabular level. Testes oval, symmetrical, postovarian; left testis $20-40(30 \pm 5.2)$ long by 39-50 (44 \pm 3.8$)$ wide; right testis 25-33 (29 \pm 2.5$)$ long by 20-30 (27 \pm 4.4$)$ wide. Cirrus-sac thin walled, curved, 150-209 (177 \pm 15.6) long, between intestinal ceca

FIGURE 5. Maritrema novaezealandensis n. sp. Sporocyst. Bar $=50 \mu \mathrm{m}$.

FIGURE 6. Maritrema novaezealandensis n. sp. Encysted metacercaria. Bar $=100 \mu \mathrm{m}$.

FIGURE 7. Maritrema novaezealandensis n. sp. Cercaria, ventral view, with stylet in frontal and side view. Bar $=50 \mu \mathrm{m}$. 

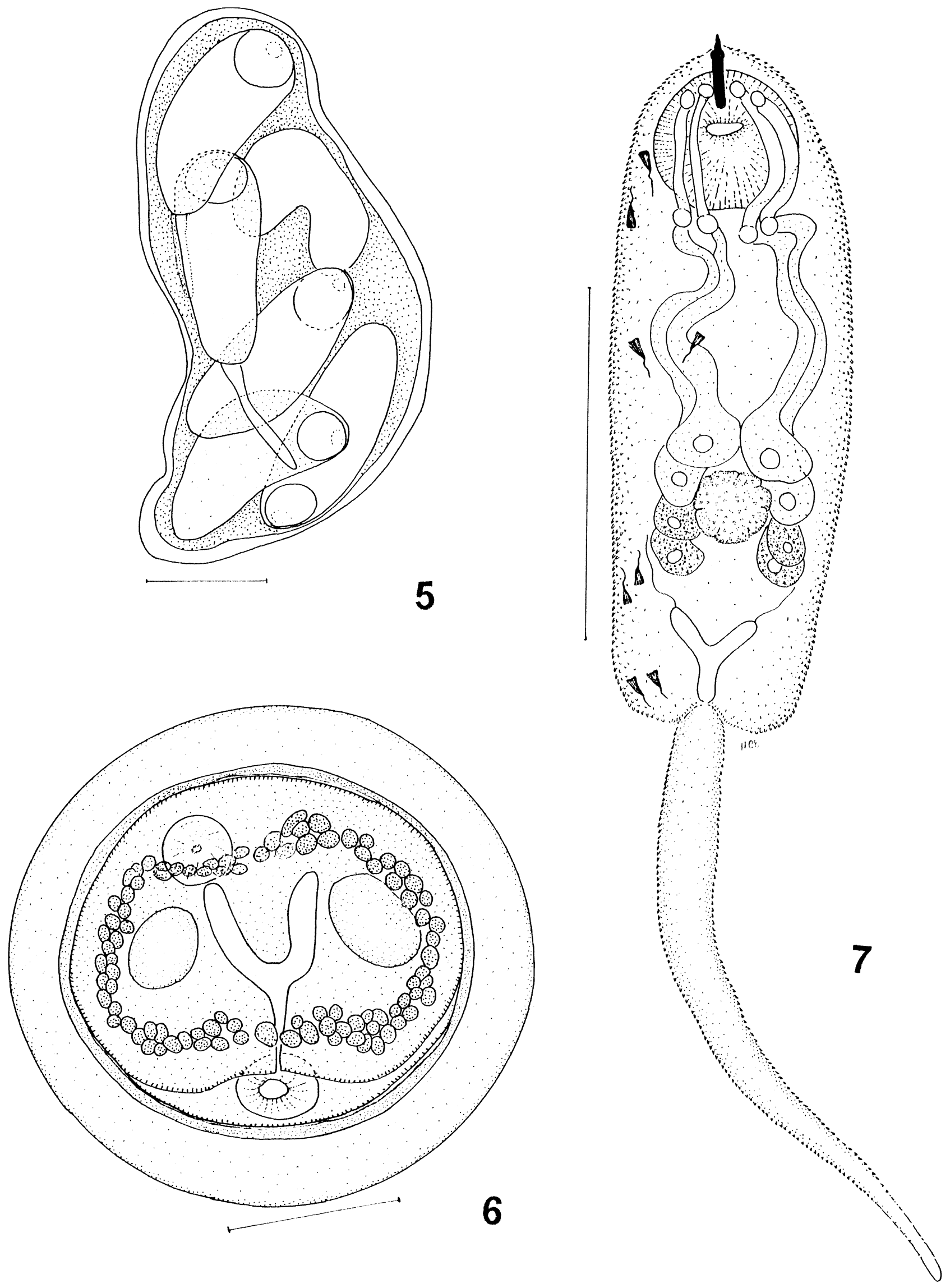


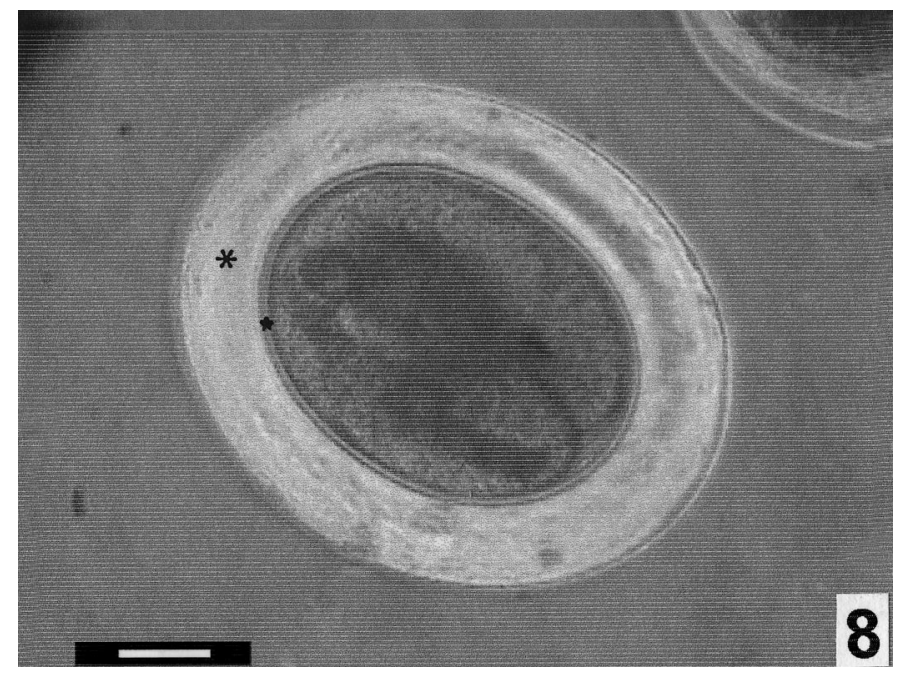

FIGURE 8. Maritrema novaezealandensis n. sp. Encysted metacercaria with enlarged external layer (8-point star) and normal internal layer (6-point star). Bar $=60 \mu \mathrm{m}$.

and VS. Cirrus-sac base close to right testis. CSL/BL $=0.45-0.41(0.48$ \pm 0.02). Cirrus-sac with oval seminal vesicle, 75-95 (85 \pm 7.4$)$ long, numerous prostatic cells, ejaculatory duct, pars prostatica, and protrusible spinous cirrus. Invaginated cirrus $65-80$ (68 \pm 8.8$)$ long by 20 $25(22 \pm 2)$ wide. Evaginated cirrus $52-68(60 \pm 8)$ long by 30-42 $(36 \pm 6)$ wide at base. Ovary middle, postacetabular, partially overlapping the posterior border of the VS, 37-60 (50 \pm 8.5) long by 20-30 $(27 \pm 4.4)$ wide. Seminal receptacle and Laurer's canal not evident. Uterus connected with thick-walled and diverticulate metraterm. Genital pore left of acetabulum. Vitellarium in a complete ring near margin of body. Excretory vesicle Y shaped, reaching anterior edge of vitellaria, and opening into the posterior body extremity. There was no discernible morphological difference between metacercariae from naturally infected hosts and those obtained from experimental infections.

Metacercariae were found in the body cavity of second intermediate hosts (H. crenulatus, $M$. hirtipes, $H$. whitei, and several unidentified amphipods). Prevalence in $H$. crenulatus and $M$. hirtipes ranges among localities sampled from 80 to $100 \%$, and intensity of infection reaches 1,000 metacercariae per crab.

Adults, excysted metacercariae, and 24- to 48-hr-old cultured metacercariae were morphologically similar. The similarities were mostly based on the genital system structure (cirrus sac, invaginated cirrus, ovary, testis, metraterm, and vitellarium). In one 24 -hr-old metacercaria, 1 immature egg was observed.

\section{DISCUSSION}

On the basis of morphological similarities, a 3-host life cycle can be proposed for this parasite. In addition, experimental infections of the crab $H$. crenulatus and the amphipod Paracalliope sp. with cercariae released from the snail Z. subcarinatus have confirmed that part of the life cycle (B. Fredensborg, unpubl.). The first intermediate host is the mud snail, Z. subcarinatus, in which the cercarial stage is produced in sporocysts located within the gonad of the snail. At least $3 \mathrm{crab}$ species (H. crenulatus, $M$. hirtipes, and $H$. whitei) and several species of amphipods act as second intermediate hosts. In all observed cases, M. novaezealandensis was found encysted in the body cavity of the crustacean host. In the experimental infections of the amphipod Paracalliope sp., fully mature metacercariae, morphologically identical to those found in naturally infected crustaceans, were obtained 4-5 wk after infection; if excysted and incubated in saline solution, these metacercariae produced eggs just as those from naturally infected hosts. Within the gull, the metacercariae excyst and grow into adults in the intestine, more specifically in the jejunum and ileum. Larus novaehollandiae scopulinus is 1 of the shorebirds known to be capable of feeding on crabs in the study area (Latham and Poulin, 2002).

The proposed life cycle for M. novaezealandensis $\mathrm{n}$. sp. is also consistent with previous reports on other species of Maritrema that have similar transmission patterns (Etges, 1953; Ching, 1963; Bridgman, 1971; Yamaguti, 1975; Prevot et al., 1976; Etchegoin and Martorelli, 1997).

\section{ACKNOWLEDGMENTS}

This study was supported in part by a grant from the Marsden Fund (New Zealand) to R. Poulin, and by grants from the Carlsberg Foundation (Denmark) and the Danish Natural Science Research Council to K.N. Mouritsen.

\section{LITERATURE CITED}

Bridgman, J. F. 1971. The life cycle of Maritrema setoenensis n. sp. (Trematoda: Microphallidae). Japanese Journal of Parasitology 20: 13-23.

ChING, H. L. 1963. The description and life cycle of Maritrema laricola sp. n. (Trematoda: Microphallidae). Canadian Journal of Zoology 41: $881-888$.

DeBlock, S. 1971. Contribution à l' étude des Microphallidae Travassos 1920. XXIV. Tentative de phylogénie et de taxonomie. Bulletin du Muséum National d' Histoire Naturelle 7: 353-468.

$\longrightarrow$, AND A. G. CANARIS. 1992. Contribution à l' étude des Microphallidae Travassos 1920. (Trematoda) XLIII-De six espèces d'Afrique du sud dont une d'un genre nouveau. Annales de Parasitologie Humaine et Comparée 67: 204-218.

, AND - 1996. Microphallidae, Trematoda. XLVIII. Quatre Maritrema du groupe Eroliae parasites d' oiseaux australiens. Parasite 4: 357-361.

, AND J. C. Pearson. 1968. Contribution à 1' étude des Microphallidae Travassos 1920. (Trematoda) XV—De quelques espèces d'Australie dont Pseudospelotrema anenteron n. sp. Annales de Parasitologie Humaine et Comparée. 43: 457-465.

Etchegoin, J. A., And S. R. Martorelli. 1997. Description of a new species of Maritrema (Digenea: Microphallidae) from Mar Chiquita coastal lagoon (Buenos Aires, Argentina) with notes on its life cycle. Journal of Parasitology 83: 709-713.

ETGES, F. J. 1953. Studies on the life histories of Maritrema obstipun (Van Cleave \& Mueller, 1932) and Levinseniella amnicolae $\mathrm{n}$. sp. (Trematoda: Microphallidae). Journal of Parasitology 39: 643-662.

Galaktionov, K. V., I. I. Malkova, S. W. B. Irwin, D. H. Saville, AND J. G. Maguire. 1997. The structure and formation of metacercarial cyst in the trematode family Microphallidae Travasos 1920. Journal of Helminthology 71: 13-20.

Hickman, V. V. 1955. On Maritrema ornithorhynchy sp. n., with a key to the genus Maritrema Nicoll. Revista Iberica de Parasitologia. Tomo Extraordinario 181-191.

Latham, A. D. M., And R. Poulin. 2002. New records of gastrointestinal helminths from the southern black-backed gull (Larus dominicanus) in New Zealand. New Zealand Journal of Zoology 29: 253-257.

Martorelli, S. R., AND M. Schuld. 1990. Encapsulación de dos metacercarias (Digenea: Microphallidae) en Cyrtograpsus angulatus y Palaemonetes argentinus (Crustacea: Decapoda). Revista de Biología Tropical. 38: 295-304.

Overstreet, R. M. 1983. Metazoan symbionts of crustaceans. In The biology of crustacea, Vol. 6, O. E. Bliss, and A. J. Provenzano (eds.). Academic Press, Inc., New York, p. 156-251.

Prevot, G., P. Bartoli, and S. Deblock. 1976. Cycle biologique de Maritrema miisenensis (A. Palombi, 1940) n. comb. (Trematoda: Microphallidae Travassos, 1920) du midi de la France. Annales de Parasitologie 51: 433-446. 
Shimazu, T., And J. Pearson. 1991. Adults and metacercariae of three microphallid trematodes including a new species of the genus Maritrema from Queensland, Australia. Japanese Journal of Parasitology 40: 533-541.

Smith, S. J. 1974. Three new microphallid trematodes from Tasmanian birds. Papers and Proceedings of the Royal Society of Tasmania 107: 197-205.
1983. Three new species and a new record of microphallid trematodes from Tasmania, with observations on their in vitro development. Papers and Proceedings of the Royal Society of Tasmania 117: 105-123.

YAmaguTI, S. 1975. A synoptical review of life histories of digenetic trematodes of vertebrates. Keigaku Publishing Co., Tokyo, Japan, $590 \mathrm{p}$. 